Vol. 8, No. 1, 2021

https://doi.org/10.23939/eem2021.01.116

UDC 338.24.01

JEL Classification Code: G32, G33, H12

O. Kuzmin

Lviv Polytechnic National University, Ukraine, Doctor of Economics, Professor

E-mail: Oleh.Y.Kuzmin@lpnu.ua ORCID: 0000-0002-6014-6437

O. Yurynets

Lviv Polytechnic National University, $\mathrm{PhD}$ in Economics, Associate Professor

E-mail: oksana.v.yurynets@lpnu.ua

ORCID: 0000-0001-9698-2499

I. Prokopenko

Lviv Polytechnic National University, PhD in Economics, Assisstant

E-mail: iryna.v.prokopenko@lpnu.ua

ORCID: 0000-0003-3178-7187

\title{
ORGANIZATIONAL CHANGES IN THE ACTIVITY OF ENTERPRISES IN THE CONTEXT OF URGENT CRISIS MANAGEMENT
}

\begin{abstract}
Eliminating or reducing the negative impact of crisis phenomena on the economic condition of an enterprise and ensuring its further effective development is closely related to the concept of organizational changes. On the one hand, urgent crisis management tools almost always cause such changes. On the other hand, crisis phenomena in the activities of a business entity lead to the need to introduce organizational changes. In this context, it is noted that it is important to diagnose such changes even before their practical implementation begins. This problem is especially relevant when it is necessary to introduce socalled large-scale changes in the context of crisis management. Any mistakes at the beginning most likely will lead to failure to achieve the set goals and to problems in the practical implementation of these changes. Consequently, based on the results of the conducted research, organizational changes in the activities of enterprises in the conditions of crisis management at the beginning are proposed to be diagnosed taking into account four areas that correspond to the PAEI-model of Adizes, well known in the theory and practice. At the same time, it provides for determining the market orientation of organizational changes (proactive nature of organizational changes); the social orientation of organizational changes (integrative nature of organizational changes); the impact of organizational changes on the enterprise administration system
\end{abstract}

(complementary nature of organizational changes); the impact of organizational changes on the operating environment of the enterprise (functional nature of organizational changes).

The article offers a method for diagnosing organizational changes in the activities of enterprises in the conditions of crisis management, based on the method of hierarchy analysis (Analytic Hierarchy Process AHP) and provides for the implementation of such key stages: the formation of an expert group; determining the level of a hierarchical model for diagnosing organizational changes in the conditions of anti-crisis management; studying the essence and characteristics of the proposed organizational changes, so that then diagnose them taking into account the directions of proactive, integrative, functional and complementary nature, using matrices of pairwise comparisons; determining eigenvectors, as well as establishing their normalized values, applying the known geometric mean of the matrix lines; determining the consistency of expert opinions; forming conclusions and recommendations. The possibility of practical use of the proposed method of diagnosing organizational changes in the activities of enterprises in the context of crisis management is confirmed by relevant calculations on the example of several business entities in the Lviv region.

Key words: crisis management, business, investment, innovation, tools, crisis, enterprise. 


\section{Organizational changes in the activity of enterprises in the context of urgent crisis management}

\section{Introduction}

In market conditions of management, crises are an integral part of the functioning of enterprises in a dynamic business environment. Business representatives, unable to avoid crisis phenomena, can still influence them by reducing their negative consequences or correcting their impact. At the same time, this makes it necessary to form effective anti-crisis management tools, primarily of an urgent nature and direction.

The study of theory and practice allows us to conclude that the elimination or reduction of the negative impact of crisis phenomena on the economic state of the enterprise and ensuring its further effective development closely correlates with the concept of organizational changes. On the one hand, urgent crisis management tools almost always cause such changes. On the other hand, crisis phenomena in the activities of a business entity lead to the need to introduce organizational changes. The company may be affected by these changes or initiate them independently. However, in general, changes are necessary.

As you know, changes are an integral part of business activity, but the attitude to changes and management varies significantly depending on the enterprise. Thus, some business entities take an active position on changes, trying to respond to them as much as possible and stay ahead of them. Other business representatives passively contemplate the changes that are taking place. As the study of theory and practice shows, in a complex dynamic environment, it is difficult to achieve success without realizing the need for change and the need for effective management of them. To achieve success in competition, you need to implement a lot of organizational changes that relate to the types of activities, markets, technologies, organizational structure of management, corporate culture, personnel, management tools, business methods, management systems, communication methods, etc.

\section{Literature review and methodical approaches}

A review and generalization of literature sources show that there are many different approaches to the interpretation of the concept of organizational changes. Some scientists consider them from the perspective of a process that covers various areas of activity of the enterprise. Others identify changes with the transition of an object from one state to another. Others still consider changes as the transformation of individual subsystems of a business entity, including those that are concerning the external environment, etc.

For different authors, organizational changes relate to the enterprise as a whole or its elements, its environment, processes, human capital, resources, and so on. They can be superficial or deep, as well as relate to significant or more general problems. Changes can be caused by both internal and external factors. Implementing changes at the enterprise should help it function more efficiently in the market and ensure profitability. Not only business entities that are in crisis but also those whose market positions are strong should consider the problems of organizational changes.

The study of theory and practice allows us to conclude that the sphere of organizational changes in the activities of enterprises, including in the conditions of crisis management, is quite carefully considered in the scientific literature. In particular, this direction highlights the problems [1-5]: the essence and specifics of organizational changes; typology of organizational changes and their basic models; basic concepts, theories and philosophy of changes; concepts and methods of effective implementation of organizational changes; stages of successful management of organizational changes; introduction of organizational changes in the conditions of innovative development of the enterprise; identification of factors that cause organizational changes; highlighting obstacles during the implementation of organizational changes; resource support of organizational changes; management of strategic organizational changes; the role of managers in the implementation of organizational changes; the human factor in the process of implementing organizational changes; reactions of various groups of stakeholders to organizational changes; formation of a mechanism for managing organizational changes; resistance to organizational changes (its causes, types, methods of management, etc.); leaders of changes; formation of trust in the implementation of organizational changes; personnel management in the process of organizational changes; psychology of organizational 


\section{O. Kuzmin, O. Yurynets, I. Prokopenko}

changes; risks of implementing organizational changes, etc.

Taking into account the importance and necessity of organizational changes, it should still be noted that their implementation should be carried out carefully and thoughtfully, using all available tools for diagnosing them for expediency. Moreover, in this context, it is worth talking about both "input" and "output" diagnostics. The first is carried out before the implementation of organizational changes, and the second - after that. Understanding the role and significance of "output" diagnostics of organizational changes in the activities of enterprises, however, in the conditions of domestic business, the key is to diagnose such changes even before their practical implementation begins. This problem is especially relevant when it is necessary to introduce so-called large-scale changes in the context of crisis management. Any mistakes at the beginning most likely will lead to failure to achieve the set goals and to problems in the practical implementation of these changes.

Considering the problems of diagnosing organizational changes in the activities of enterprises in the context of crisis management, it is necessary to choose certain methodological tools in this context. To achieve these goals, we should use the well-known method of hierarchy analysis (AHP) in scientific research, which is based on the construction and analysis of matrices of pairwise comparisons. According to the review and generalization of literature sources, nowadays the AHP method is used not only to solve various management problems but also in other industries where it is necessary to choose alternatives, allocate resources, prioritize some options over others, predict scenarios, etc.

The study of theory and practice shows that in the most generalized form, the practical use of the hierarchy analysis method involves the implementation of three key stages, namely [6-11]:

- building a hierarchical model that includes goals, criteria, and alternatives;

- construction of matrices of pairwise comparisons using expert judgments;

- calculation of estimates of the significance of alternatives based on criteria at all levels, according to the principle of hierarchical composition.
According to the review and generalization of literature sources, in economic research, the method of hierarchy analysis is used, for example, for:

- assessment of managers' competencies;

- value-based management;

- choosing a strategy;

- environmental impact assessment;

- selection of suppliers;

- assessment of labour relations during the dismissal of employees;

- identification of key possible enterprises;

- identification of critical success factors for the information services industry in the international market;

- analysis of barriers to implementing "green" supply chain management;

- development of an approach to the formation of indicators of agricultural sustainability;

- outsourcing of non-core assets and competencies of the enterprise;

- assessment of safety risk during planning and budgeting of construction projects;

- ranking of human capital indicators;

- development of a demand response prelabour emergencies, etc.

The use of the hierarchy analysis method to solve the problem of diagnosing organizational changes in the activities of enterprises in the conditions of crisis management is due to its strong sides, namely $[6 ; 9 ; 11,12]$ :

- ability to take into account the level of consistency of specialists' opinions;

- ability to structure a task that itself belongs to the category of poorly formalized ones;

- ability to rate alternative management solutions;

- ability to attract external specialists to the choice of alternatives, if necessary;

- ability to consider a complex problem from an analytical point of view;

- ability to apply both deterministic and qualitative diagnostic parameters;

- ability to evaluate parameters that either do not lend themselves to mathematical formalization at all, or it can be done at a rather low level; 
- ability to rank experts according to their competence and significance for achieving goals, and so on.

\section{Results}

Based on the results of the conducted research, organizational changes in the activities of enterprises in the conditions of crisis management at the beginning are proposed to be diagnosed taking into account four areas that correspond to the PAEI-model of Adizes, well known in the theory and practice [13] (Fig. 1).

Based on the results of long-term research, Adizes concluded that any organization (commercial or non-profit) should be effective and efficient in both the short and long term. And for this to happen, it must play four roles [13]:

- producing $(\mathrm{P})$;

- administering (A);

- entrepreneuring (E);

- integrating (I).

According to the author of the theory, thanks to the first two roles, the business entity is effective and efficient in the short term, and thanks to the other two, it is effective and efficient in the long term.

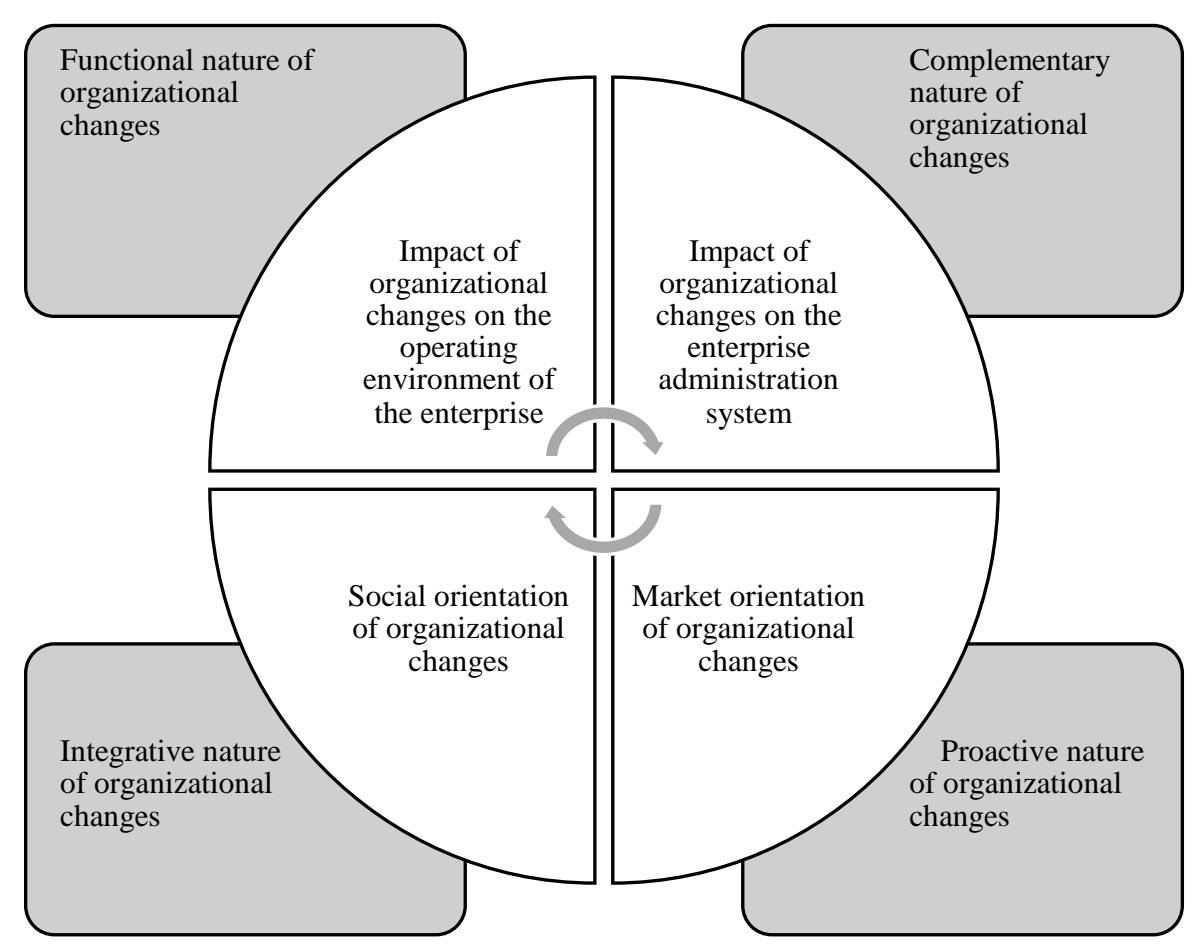

Fig. 1. Directions of diagnostics of organizational changes in the activities of enterprises in the context of crisis management

Note: proposed by the authors taking into account [13]

Nowadays the Adizes' PAEI model in the scientific literature is used to solve a wide range of problems, in particular:

- to study organizational characteristics at the first three stages of the life cycle;

- $\quad$ in the personnel management of a small enterprise in the field of agricultural tourism;

- to identify the relationship between students' behaviour in video presentations and their modality;

- for evaluating management in a small enterprise;
- $\quad$ to study the ability to manage and ensure privacy, etc.

In the case of organizational changes in the activities of enterprises in the context of crisis management, it should be noted that their functional nature (impact on the operating environment of the enterprise) indicates the provision of the expected result due to such changes, which is the satisfaction of the needs of the so-called "clients of changes" (we are talking about the added value of organizational changes in the context of the operating environment). Drawing parallels with the results of research by 


\section{O. Kuzmin, O. Yurynets, I. Prokopenko}

Adizes [13], such "clients of change" can be both representatives of the internal and external environment. On the other hand, each organizational change in the context of crisis management has its own "client" (or "clients"), to which it is directed (for example, to the department, to the direction of activity, to the geographical market, to technological processes, to ways of interacting with suppliers, etc.). Adizes interprets the concept of "client" much more broadly than the concept of "goal" because the goal can not always be achieved, however, in our case, the "client of change" can still interpret organizational change very effectively. In addition, it should be taken into account that the goals of developing and implementing such changes can be significantly modified and even changed in the course of project work.

The impact of organizational changes on the enterprise administration system (the complementary nature of organizational changes) means that each such change should not be isolated or separate in relation to the processes that occur in the business entity's activities. On the contrary, it should harmoniously "fit" into such processes, balance and complement them. This should be taken into account, because the realities of today show that quite often the goals of implementing organizational changes in the conditions of crisis management are achieved, at the same time, these changes have a destructive effect on the management system of the enterprise, on the established procedures and lead to inefficiency of the business entity.

It is also necessary to diagnose organizational changes in the activities of enterprises in the context of crisis management in the direction of their market orientation (proactive nature of organizational changes). The fact is that nowadays every enterprise operates in a very dynamic business environment, where everything happens quickly (for example, you should respond quickly to problems, act quickly in response to changing consumer needs, quickly deliver products to the points of sale, etc.). In this context, using the terminology of Adizes, the organizational changes in the context of crisis management should "meet changing realities". They should contribute to the development of the enterprise, they should take into account the perspective, "see through the fog", they should "take into account changes".

The last proposed direction for diagnosing organizational changes in the company's activities in the context of crisis management is the direction of their social orientation (integrative nature of organizational changes). This direction is aimed at the social aspects of management and the social subsystem of the business entity. Organizational changes should bring employees together or contribute to this, which will ensure teamwork, team spirit, team motivation, synchronization of all employees of the department/enterprise, etc.

Using the conceptual, category and methodological apparatus of the hierarchy analysis method (Analytic Hierarchy Process - AHP), which are described in the above-mentioned literature sources, the problem of diagnosing organizational changes in the activities of enterprises in the conditions of crisis management can be represented mainly with the construction of matrices of pairwise comparisons $A=\left(a_{i j}\right)$, whose characteristic is a single diagonal. At its core, each such matrix will clearly show the predominance of option $i$ above option $j$ for each comparison option. In addition, given the phenomenon of inverse symmetry within the framework of the hierarchy analysis method, it is true that $a_{j i}=\frac{1}{a_{i j}}$.

In the case of diagnosing organizational changes in the activities of enterprises in the context of crisis management, it is not a task in choosing alternative options for such changes (where most often the method AHP is exactly what is used), but in the definition:

- market orientation of organizational changes (proactive nature of organizational changes);

- social orientation of organizational changes (integrative nature of organizational changes);

- impact of organizational changes on the enterprise administration system (complementary nature of organizational changes);

- influence of organizational changes on the operating environment of the enterprise (functional nature of organizational changes).

Considering individual stages of diagnosing organizational changes in the activities of enterprises in the context of crisis management using the hierarchy analysis method, first an expert group 
should be formed that will perform all further work. These experts should not have a conflict of interest among themselves, be competent in terms of the proposed organizational changes, as well as in terms of practical use of the AHP-method. If necessary, the expert group may also include external specialists.

The formation of an expert group makes it possible to determine the level of the hierarchical diagnostic model of organizational changes in the activities of enterprises in the context of crisis management. In our case, we should take into account

$$
\theta=\left\{n_{1}, n_{2}\right\},(1)
$$

where $\theta$ is comparison options for assessing organizational changes in the activities of enterprises in the context of crisis management; $n_{1}$ - directions of diagnostics of organizational changes in the activities of enterprises in the conditions of crisis management (market orientation of organizational changes; social orientation of organizational changes; the impact of organizational changes on the enterprise administration system; the impact of organizational changes on the operating environment of the enterprise); $n_{2}$ - organizational changes in the activities of enterprises in the context of crisis management.

Taking into account the above, let us give a two-level hierarchical model for diagnosing organizational changes in the activities of enterprises in the context of crisis management (Fig. 2).

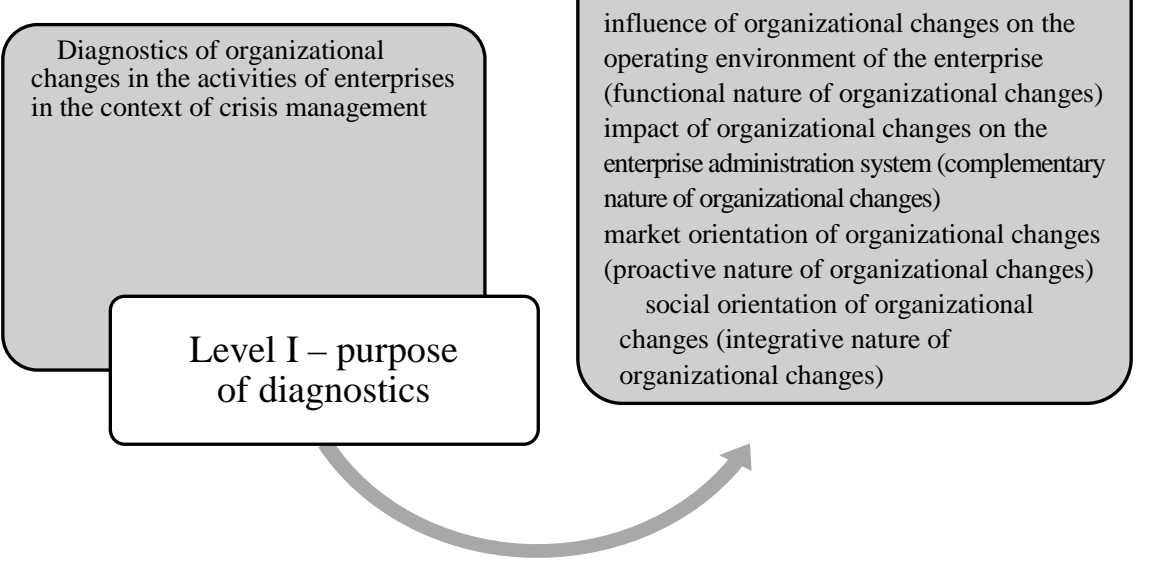

Fig. 2. A hierarchical model of diagnostics of organizational changes in the activities of enterprises in the context of crisis management

Note: created by the authors

During the practical use of the proposed method for diagnosing organizational changes in the activities of enterprises in the context of crisis management, it is possible to increase the number of these levels to three, four or more, if necessary.

In the future, it is necessary to carefully study the essence and characteristics of

$$
A=\left[\begin{array}{cccccc}
1 & a_{12} & \ldots & a_{1 j} & \ldots & a_{1 n} \\
a_{21} & 1 & \ldots & a_{2 j} & \ldots & a_{2 n} \\
\ldots & \ldots & 1 & \ldots & \ldots & \ldots \\
a_{i 1} & a_{i 2} & \ldots & 1 & \ldots & a_{i n} \\
\ldots & \ldots & \ldots & \ldots & 1 & \ldots \\
a_{n 1} & a_{n 2} & \ldots & a_{n j} & \ldots & 1
\end{array}\right], a_{i i}=1, a_{j i}=\frac{1}{a_{i j}}, i, j=1,2, \ldots, n,
$$

where $a_{i j}$ - matrix elements $A=\left(a_{i j}\right)$, showing the predominance of the option $i$ on the option $j$ the proposed organizational changes in the company's activities in the context of crisis management, in order to then diagnose them taking into account the directions of proactive, integrative, functional and complementary nature, using matrices of pairwise comparisons $A=\left(a_{i j}\right)$ :

for each direction of diagnostics of organizational changes in the activities of enterprises in the 


\section{O. Kuzmin, O. Yurynets, I. Prokopenko}

conditions of crisis management (option $i$ applies to the matrix row, and the option $j-$ its column); $n-$ number of comparison options.

It is also obvious that each element of an inversely symmetric matrix $A=\left(a_{i j}\right)$ will acquire only positive values, i.e. $A=\left(a_{i j}\right) a_{i j}>0$ for each $i, j=1, \ldots, n$. Moreover, it is necessary to take as a basis the relative scales of diagnostics of organizational changes in the activities of enterprises in the conditions of crisis management in areas based on the known 9-point Saati scale within the frameworks of the AHP method (Table 1).

Similar relative scales for diagnosing organizational changes in the company's activities in the context of crisis management should be built in the other three areas.

Table 1

\section{The relative scale of diagnostics of organizational changes in the company's activities in the context of crisis management in the direction of their market orientation (proactive nature)}

\begin{tabular}{|c|l|}
\hline Scores & \multicolumn{1}{c|}{ Characteristics } \\
\hline 1 & $\begin{array}{l}\text { Organizational changes in the company's activities in the context of crisis management } \\
\text { have the most positive market orientation }\end{array}$ \\
\hline 3 & $\begin{array}{l}\text { Organizational changes in the company's activities in the context of crisis management } \\
\text { have a favourable market orientation }\end{array}$ \\
\hline 5 & $\begin{array}{l}\text { Organizational changes in the company's activities in the context of crisis management } \\
\text { taking into account the market orientation generally have a neutral impact }\end{array}$ \\
\hline 7 & $\begin{array}{l}\text { Organizational changes in the company's activities in the context of crisis management } \\
\text { have a negative market orientation }\end{array}$ \\
\hline 9 & $\begin{array}{l}\text { Organizational changes in the company's activities in the context of crisis management } \\
\text { have the most negative market orientation }\end{array}$ \\
\hline $2,4,6,8$ & Tentative scores \\
\hline
\end{tabular}

Note: developed based on [14]

Having constructed inversely symmetric matrices using relative scales for diagnosing organizational changes in the company's activities in the context of crisis management $A=\left(a_{i j}\right)$, in the future eigenvectors for each of them should be defined, as well as their normalized values should be set using the known geometric mean of the matrix rows $A=\left(a_{i j}\right)$ :

$$
x_{i}=\sqrt[n]{\prod_{j=1}^{n} a_{i j},} \quad i, j=1,2, \ldots, n,
$$

where $x_{i}-i$-the value of the element of the eigenvector of the matrix $A=\left(a_{i j}\right)$.

Within the framework of the proposed method for diagnosing organizational changes in the company's activities in the context of crisis management the normalized values of the priority vector should be calculated using the formula:

$$
y_{i}=\frac{x_{i}}{\sum_{i=1}^{n} x_{i}}
$$

where $y_{i}$ - normalized value $i-$ of the value of an element.

Given the potential differences in experts opinions about the benefits of option $i$ on option $j$ for each direction of diagnosing organizational changes in the activities of enterprises in the context of crisis management, within the framework of the hierarchy analysis method, it is proposed to determine the consistency of the opinions of these experts. Corresponding Consistency Index $I_{u}$ is calculated using the formula:

$$
I_{u}=\frac{\gamma_{\max }-n}{n-1}
$$

where $\gamma_{\max }-$ is a maximum possible eigenvalue of each matrix $A=\left(a_{i j}\right)$.

Determining the consistency index $I_{u}$ in the frameworks of the method of diagnosing organizational changes in the activities of enterprises in the context of crisis management it requires information about a random consistency index $V_{i u}$, which is also given in the work of $\mathrm{T}$. Saati (Table 2). 
Table 2

Random consistency index $V_{i u}$ of matrices $A=\left(a_{i j}\right)$ in the frameworks of the method of diagnosing organizational changes in the activities of enterprises in the context of crisis management

\begin{tabular}{|c|c|c|c|c|c|c|c|c|c|c|c|c|c|c|c|}
\hline $\begin{array}{c}\text { Matrix } \\
\text { level }\end{array}$ & 1 & 2 & 3 & 4 & 5 & 6 & 7 & 8 & 9 & 10 & 11 & 12 & 13 & 14 & 15 \\
\hline Value $V_{i u}$ & 0.00 & 0.00 & 0.58 & 0.90 & 1.12 & 1.24 & 1.32 & 1.41 & 1.45 & 1.49 & 1.51 & 1.48 & 1.56 & 1.57 & 1.59 \\
\hline
\end{tabular}

Note: taking into account $[11 ; 14]$.

The possibility of practical use of the proposed method of diagnosing organizational changes in the activities of enterprises in the context of crisis management is confirmed by relevant calculations on the example of several business entities in the Lviv region. In particular, we will present the following calculations for Vynnykivska Tobacco Factory LLC. At one time, the management of this business entity considered the option of technological modernization of production facilities with an emphasis on innovation, which was caused by the weakening of the company's market position and its relative crisis state. Decision-making was based on the criteria of technological innovation, which are justified in the literature. At this stage, the heads of the institutional level of management of Vynnykivska Tobacco Factory LLC were asked to take into account the method of diagnosing organizational changes in the conditions of crisis management. As a result, a working group of 5 people was formed, which brought together both internal and external experts (in a $3 \times 2$ ratio). The form of work of this expert group is periodic sessions, during which the methods of "brainstorming" and expert focusing were used. The average values method is used to determine the average estimates.

During the practical application of the method for diagnosing organizational changes in the context of crisis management, there was no increase in the number of levels of the hierarchical model (the two levels mentioned above were taken into account). Also, as noted above, the diagnostic areas mentioned are used, namely: proactive, integrative, complementary and functional nature of organizational changes. For each of them, the relative scales shown in Table 1 are used, which made it possible to construct 4 matrices of pairwise comparisons $A=\left(a_{i j}\right)$.
As noted above, the use of the method of diagnosing organizational changes in the activities of enterprises in the context of crisis management also involves the construction of matrices of pairwise comparisons for second-level areas (Table 3).

Taking into account the given formulas (3) and (4), we obtain the following calculations:

$$
\begin{gathered}
x_{1}=\sqrt[4]{1 \times \frac{1}{5} \times \frac{1}{3} \times \frac{1}{3}}=0.39 ; \\
x_{2}=\sqrt[4]{5 \times 1 \times 3 \times 3}=2.59 ; \\
x_{3}=\sqrt[4]{3 \times \frac{1}{3} \times 1 \times 3}=1.32 ; \\
x_{4}=\sqrt[4]{3 \times \frac{1}{3} \times \frac{1}{3} \times 1}=0.76 ; \\
\sum_{i=1}^{4} 0.39+2.59+1.32+0.76=5.05 ; \\
y_{1}=\frac{0.39}{5.05}=0.0772 ; \\
y_{2}=\frac{2,59}{5.05}=0.5129 ; \\
y_{3}=\frac{1.32}{5.05}=0.2614 ; \\
y_{4}=\frac{0.76}{5.05}=0.1505
\end{gathered}
$$

$\gamma_{\max }$ for Vynnykivska Tobacco Factory LLC at the second level of the hierarchical model for the directions of diagnostics of the proposed organizational change will be:

$$
\begin{aligned}
\gamma_{\max }=0.0772 & \times(3+5+1+3)+0.5129 \\
& \times\left(\frac{1}{5}+1+\frac{1}{3}+\frac{1}{3}\right)+0.2614 \\
& \times\left(\frac{1}{3}+3+1+\frac{1}{3}\right)+0.1505 \\
& \times\left(\frac{1}{3}+3+3+1\right)=4.2073
\end{aligned}
$$


Table 3

Matrix of pairwise comparisons for Vynnykivska Tobacco Factory LLC at the second level of the hierarchical model for the directions of diagnostics of the proposed organizational change

\begin{tabular}{|c|c|c|c|c|c|}
\hline Parameters & $\begin{array}{l}\text { Impact of the } \\
\text { analyzed } \\
\text { organizational } \\
\text { change on the } \\
\text { operating } \\
\text { environment } \\
\text { (functional nature of } \\
\text { the proposed } \\
\text { organizational } \\
\text { change) }\end{array}$ & $\begin{array}{l}\text { Impact of the } \\
\text { analyzed } \\
\text { organizational } \\
\text { change on the } \\
\text { administration } \\
\text { system } \\
\text { (complementary } \\
\text { nature of the } \\
\text { proposed } \\
\text { organizational } \\
\text { change) }\end{array}$ & $\begin{array}{l}\text { Market orientation } \\
\text { of the analyzed } \\
\text { organizational } \\
\text { change (proactive } \\
\text { nature of the } \\
\text { proposed } \\
\text { organizational } \\
\text { change) }\end{array}$ & $\begin{array}{l}\text { Social orientation of } \\
\text { the analyzed } \\
\text { organizational } \\
\text { change (integrative } \\
\text { nature of the } \\
\text { proposed } \\
\text { organizational } \\
\text { change) }\end{array}$ & $\begin{array}{l}\text { Normalized } \\
\text { rating, } y_{i}\end{array}$ \\
\hline $\begin{array}{l}\text { Impact of the } \\
\text { analyzed } \\
\text { organizational } \\
\text { change on the } \\
\text { operating } \\
\text { environment } \\
\text { (functional nature } \\
\text { of the proposed } \\
\text { organizational } \\
\text { change) }\end{array}$ & 1 & $1 / 5$ & $1 / 3$ & $1 / 3$ & 0.0772 \\
\hline $\begin{array}{l}\text { Impact of the } \\
\text { analyzed } \\
\text { organizational } \\
\text { change on the } \\
\text { administration } \\
\text { system } \\
\text { (complementary } \\
\text { nature of the } \\
\text { proposed } \\
\text { organizational } \\
\text { change) }\end{array}$ & 5 & 1 & 3 & 3 & 0.5129 \\
\hline $\begin{array}{l}\text { Market orientation } \\
\text { of the analyzed } \\
\text { organizational } \\
\text { change (proactive } \\
\text { nature of the } \\
\text { proposed } \\
\text { organizational } \\
\text { change) }\end{array}$ & 3 & $1 / 3$ & 1 & 3 & 0.2614 \\
\hline $\begin{array}{l}\text { Social orientation of } \\
\text { the analyzed } \\
\text { organizational } \\
\text { change (integrative } \\
\text { nature of the } \\
\text { proposed } \\
\text { organizational } \\
\text { change) }\end{array}$ & 3 & $1 / 3$ & $1 / 3$ & 1 & 0.1505 \\
\hline \multicolumn{6}{|c|}{$\begin{array}{c}\gamma_{\max }=4.2073 \\
I_{u}=0.0691\end{array}$} \\
\hline
\end{tabular}


Consistency Index $I_{U}$ of the expert assessments of specialists who performed the calculations цфі:

$$
I_{u}=\frac{\gamma_{\max }-n}{n-1}=\frac{4.2073-4}{4-1}=0.0691 .
$$

Using the information from Table 2 relative to the random consistency index of $V_{i u}$ matrices $A=\left(a_{i j}\right)$ within the framework of the method of diagnosing organizational changes in the activities of enterprises in the context of crisis management, we will have:

$$
V_{u}=\frac{I_{u}}{V_{i u}}=\frac{0.0691}{0.9000}=0.0768 .
$$

Compliance with the condition $V_{u} \leq 0.10$ indicates the consistency of expert assessments of specialists who performed calculations within the framework of the diagnostic method of the proposed organizational change in the activities of Vynnykivska Tobacco Factory LLC in the conditions of crisis management.

At the final stage of using the method of diagnosing the proposed organizational change in the activities of Vynnykivska Tobacco Factory LLC in the context of crisis management, a consolidated vector of priorities was proposed:

$$
\left[\begin{array}{llll}
0.1673 & 0.2511 & 0.1254 & 0.1254 \\
0.8327 & 0.7489 & 0.8746 & 0.8746
\end{array}\right]\left[\begin{array}{l}
0.0772 \\
0.5129 \\
0.2614 \\
0.1505
\end{array}\right] \text {. }
$$

As a result, we get the following calculations for the priority vector: $C$ :

$$
\begin{gathered}
c_{11}=a_{11} \times b_{11}+a_{12} \times b_{21}+a_{13} \times b_{31}+a_{14} \times b_{41}= \\
=0.1673 \times 0.0772+0.2511 \times 0.5129+0.1254 \times 0.2614+0.1254 \times 0.15=0.1933 ; \\
c_{21}=a_{21} \times b_{11}+a_{22} \times b_{21}+a_{23} \times b_{31}+a_{24} \times b_{41} \\
=0.8327 \times 0.0772+0.7489 \times 0.5129+0.8746 \times 0.2614+0.8746 \times 0.1505=0.8086 .
\end{gathered}
$$

\begin{tabular}{|c|c|c|c|c|c|}
\hline \multirow{3}{*}{ Comparison options } & \multicolumn{4}{|c|}{ Value of comparison parameters } & Final scores \\
\hline & $\begin{array}{l}\text { Impact of the } \\
\text { analyzed } \\
\text { organizational } \\
\text { change on the } \\
\text { operating } \\
\text { environment } \\
\text { (functional nature } \\
\text { of the proposed } \\
\text { organizational } \\
\text { change) }\end{array}$ & $\begin{array}{l}\text { Impact of the } \\
\text { analyzed } \\
\text { organizational } \\
\text { change on the } \\
\text { administration } \\
\text { system } \\
\text { (complementary } \\
\text { nature of the } \\
\text { proposed } \\
\text { organizational } \\
\text { change) }\end{array}$ & $\begin{array}{c}\text { Market } \\
\text { orientation of the } \\
\text { analyzed } \\
\text { organizational } \\
\text { change (proactive } \\
\text { nature of the } \\
\text { proposed } \\
\text { organizational } \\
\text { change) }\end{array}$ & $\begin{array}{l}\text { Social orientation } \\
\text { of the analyzed } \\
\text { organizational } \\
\text { change (integrative } \\
\text { nature of the } \\
\text { proposed } \\
\text { organizational } \\
\text { change) }\end{array}$ & \\
\hline & 0.0772 & 0.5129 & 0.2614 & 0.1505 & \\
\hline $\begin{array}{c}\text { Analyzed } \\
\text { organizational } \\
\text { change }\end{array}$ & 0.1673 & 0.2511 & 0.1254 & 0.1254 & 0.1933 \\
\hline $\begin{array}{l}\text { Directions for } \\
\text { diagnosing the } \\
\text { analyzed } \\
\text { organizational } \\
\text { change }\end{array}$ & 0.8327 & 0.7489 & 0.8746 & 0.8746 & 0.8086 \\
\hline
\end{tabular}

The generalized calculation results are presented in Table 4 .

Table 4

\section{Generalized results of diagnostics of the proposed organizational change in the activities of Vynnykivska Tobacco Factory LLC}

The results, given in Table 4, show to a greater extent the inexpediency of implementing the proposed organizational change regarding the technological modernization of the enterprise's production facilities with an emphasis on innovation. 


\section{O. Kuzmin, O. Yurynets, I. Prokopenko}

\section{Conclusion}

The article offers a method for diagnosing organizational changes in the activities of enterprises in the conditions of crisis management, based on the method of hierarchy analysis (Analytic Hierarchy Process - AHP) and provides for the implementation of such key stages: the formation of an expert group; determining the level of a hierarchical model for diagnosing organizational changes in the conditions of anti-crisis management; studying the essence and characteristics of the proposed organizational changes, so that then diagnose them taking into account the directions of proactive, integrative, functional and complementary nature, using matrices of pairwise comparisons; determining eigenvectors, as well as establishing their normalized values, applying the known geometric mean of the matrix lines; determining the consistency of expert opinions; forming conclusions and recommendations. The possibility of practical use of the proposed method of diagnosing organizational changes in the activities of enterprises in the context of crisis management is confirmed by relevant calculations on the example of several business entities in the Lviv region. In particular, the calculations for Vynnykivska Tobacco Factory LLC are given.

\section{References}

1. Choi, M. (2011). Employees' Attitudes Toward Organizational Change: A Literature Review. Human Resource Management, 50 (4), 479-500.

2. Jana, T. \& Diaz Mejias, A. (2018). Erasing Institutional Bias: How to Create Systemic Change for Organizational Inclusion (First ed.). Oakland, CA: Berrett-Koehler Publishers.

Hughes, M. (2016). The Leadership of Organizational Change (First ed.). New York: London.
5. O'Donovan, G. (2018). Making Organizational Change Stick: How to Create a Culture of Partnership Between Project and Change Management. Abingdon, Oxon; New York, NY; Routledge.

6. Schwarz, G. M., Buono, A. F. \& Adams, S. M. (2019). Preparing for High Impact Organizational Change: Experiential Learning and Practice. Cheltenham, UK; Northampton, MA, USA: Edward Elgar Publishing.

7. Brunelli, M. (2014). Introduction to the Analytic Hierarchy Process. Springer.

8. Dyer, J. S. (1990). Remarks on the Analytic Hierarchy Process. Management Science, 36 (3), 249-258.

9. Forman, E. H. \& Gass, S. I. (2001). The Analytic Hierarchy Process - an Exposition. Operations Research, 49 (4), 469-486.

10. Liu, F. H. F. \& Hai, H. L. (2005). The Voting Analytic Hierarchy Process Method for Selecting Supplier. International Journal of Production Economics, 97 (3), 308-317.

11. Ramanathan, R. (2001). A Note on the Use of the Analytic Hierarchy Process for Environmental Impact Assessment. Journal of Environmental Management, 63 (1), 27-35.

12. Saaty, T. L. (2008). Decision Making with the Analytic Hierarchy Process. International Journal of Services Sciences, 1(1), 83-98.

13. Abdullah, L., Jaafar, S. \& Taib, I. (2013). Ranking of Human Capital Indicators Using Analytic Hierarchy Process. Procedia-Social and Behavioral Sciences, 107, 22-28.

14. Adizes, I. (2004). The Ideal Executive: Why You Cannot Be One and What to Do About It, A New Paradigm for Management. Adizes Inst.

15. Wind, Y. and Saaty, T., 1980. Marketing Applications of the Analytic Hierarchy Process. Management Science, 26 (7), 641-658. 